\title{
Monitoring System for Producing and Utilizing Fly Ash and Bottom Ash Waste from Coal Fired Power Plant to support The Cost Efficiency of Infrastructure Development
}

\author{
Mekkadinah $^{1}$, Suyud Warno Utomo ${ }^{2}$, Iwa Garniwa ${ }^{3}$, and Haruki Agustina ${ }^{4}$ \\ \{mekkadinah@gmail.com ${ }^{1}$, suyud.si@ui.ac.id², iwa.garniwa@ui.ac.id³ \\ Environmental Science School, Indonesia University, SIL-UI, Jakarta, Indonesia ${ }^{1,2}$ \\ Electrical Engineering Department, Indonesia University, Depok, Jawa Barat, Indonesia ${ }^{3}$
}

\begin{abstract}
Coal fired power plant (CFPP) capacity in Indonesia continues to grow, that also increase the amount of fly ash and bottom ash (FABA) waste produced from the CFPP. The FABA waste can be used as a mixture of cement in infrastructure development. The management of FABA waste is currently $70 \%$ utilized by the cement industry for activities located outside the power plant region, so that additional transportation costs are needed for the management of the waste. How to systematically organize institutional infrastructure and physical infrastructure to sustain recycling mechanisms or waste management is the problem. This research has an objective to find out the aspect of waste management system that could increase the usage of FABA to support cost of raw material efficiency in infrastructures. The method to find this research objective is using the sequential mixed methods. A monitoring system for the establishment and utilization of FABA waste can be built to improve waste utilization, prevent environmental and cost impacts due to further waste travel, then build the 'sound material cycle society' to promote FABA as raw material.
\end{abstract}

Keywords: System, Fly Ash, Bottom Ash, Waste, Material cycle

\section{Introduction}

The Government of Indonesia has set a National Energy General Plan that called by RUEN for the 2017-2050 period, with the dominance of the use of coal as the main energy source of power generation at $30 \%$ in year 2050. Supply of electricity using coal beside producing waste air emissions, also produces Fly ash and Bottom ash (FABA) which is generally called coal combustion products (CCPs). According to Government Regulation number 101 of 2014 (PP 101) concerning the management of hazardous waste, FABA is categorized as a waste containing hazardous material, its management regulations and permits are needed to reduce environmental impact [6]. Meanwhile Indonesia is currently increasing infrastructure development. The construction of both roads and housing requires materials which can be substituted by FABA [3], [4], [9]. Best practice for this substitute has applied in Japan, that can use FABA 97\% for infrastructure [14]. 
Development of infrastructure need cement as raw material that costly. Several researches already implemented that FABA could substitute cement [1], [10], [12]. Recently, global concern to implement reduce, reuse and recycle in every sector, including energy and infrastructure. Then, the CFPPs as the producer of FABA need to inform the infrastructure sector about their product and so vice versa. The objective of this research is to find out the aspect of waste management system that could increase the usage of FABA to support cost of raw material efficiency in infrastructures.

\section{Methods}

This research was carried out in stages, starting with a quantitative calculation of the number of FABA formed based on the number of CFPPs operating, then a qualitative analysis of the relationship between the FABA producer and its beneficiaries was carried out. The methodology of this research is the sequential mixed methods.

\section{Results and Discussions}

\subsection{Waste Production}

The domination of electricity energy supply in Indonesia generated from coal combustion on CFPP, with data stated in Indonesia Electricity Plan 2017-2024 that called as RUPTL [13]. Consumption of coal in the CFPP show as Table 1.

Table 1. Coal Consumption in CFPP

\begin{tabular}{cc}
\hline Year & Volume (Ton) \\
\hline 2011 & $25,802,724.2$ \\
\hline 2012 & $43,901,826.4$ \\
\hline 2013 & $52,639,394.9$ \\
\hline 2014 & $61,045,859.3$ \\
\hline 2015 & $66,223,221.9$ \\
\hline 2016 & $75,946,240.1$ \\
\hline
\end{tabular}

From data consumption of coal in CFPP show that increase from year 2011 until year 2016, it is mean that the waste that produce from the CFPP also increasing. Ramme and Tharaniyil [12], has calculated that CCPs productions as FABA from the CFPP approximately $5 \%$ of the coal consumption. The production of FABA show in Table 2. 
Table 2. FABA Production

\begin{tabular}{cc}
\hline Year & Volume (Ton) \\
\hline 2011 & $1,290,136.21$ \\
\hline 2012 & $2,195,091.32$ \\
\hline 2013 & $2,631,969.75$ \\
\hline 2014 & $3,052,292.97$ \\
\hline 2015 & $3,311,161.09$ \\
\hline 2016 & $3,797,312.01$ \\
\hline
\end{tabular}

Production of FABA increase from year to year, this should treat as material resource, because waste is equal with useful resources [7].

\subsection{Waste Utilization}

Before utilizing the FABA it is needed to have quality test of FABA, to ensure that FABA meet the requirement of construction standard. Quality test of FABA as CCPs in Indonesia has conducted by PLN and PUSJATAN [11] to ensure that FABA characteristics meet requirement as substitution material for cement and concentration of hazardous compound are below the limit of PP 101 regulation. The result shown that Fly Ash meet class F standard and Bottom Ash meet class $\mathrm{C}$ standard as substitution material for cement, with very trace hazardous compound.

Utilization of FABA in Indonesia only from 6 of 70 unit CFPP that produce FABA. In the otther side Indonesia need to development infrastructure that several material could replace by FABA. Munir [10] and Suseno et. al. [16] has analize that FABA could replace cement consumption around $25-50 \%$ in production of paving block for construction infratructure.

\subsection{Monitoring System and Regulation Support}

How regulation encourage sustainability in case of utilized FABA as CCPs that UNEP [14] has analyzed that Japan experience shows that a mix of policies helped it turn challenges into opportunities. Regulations to hold waste generators responsible, voluntary measures for industries, market-based instruments to subsidize city-level action, and awareness-raising program were all part of the mix that helped change attitudes and practices in industrial waste management [14]. Japan and India are best practices in policies that encourage the use of CCPs. Government partnerships in setting regulations with industry roles in harmony. India even utilizes CCPs not only for construction but also as fertilizer, land restoration, increased absorption of ground water etc. all efforts to increase the utilization of these CCPs while still monitoring the utilization process. However, it does not require complex permit for these uses. Through comparison lessons from the 'sound material cycle society' policy of Japan, recycling is not only about technical solutions or engineering of resource-recovery from waste. Rather, it is an issue of how to systematically organize institutional infrastructure and physical infrastructure to sustain recycling mechanisms or waste management. Both countries show that how regulation could encourage sustainability in case of utilized CCPs. It is different policies in Indonesia, that CCPs regulate as Hazardous Waste without any supporting system to drive 
the utilization of FABA as recycle resources. Indonesia has FABA as CCPs tha could manage as useful resouces [7], with volume increase from 1,290,136.21 ton in 2011 year to 3,797,312.01 ton in 2016 year. Recently Environmental Ministry has developed SIRAJA LIMBAH as monitoring system, but it is only for internal information for the government. It is need to improved by developed Montoring System that will give an information for the user of waste as raw material because to day globaly face the industry 4.0 [2]. The information added are about location, volume and quality of the FABA. This Monitoring System should could be access by the FABA Producer and the User that will utilize the FABA. A monitoring system for the establishment and utilization of FABA waste can be built to improve waste utilization, prevent environmental impacts due to further waste travel as LCA in infrastructure, and support increased infrastructure development in the region at a lower cost because it utilizes FABA as a substitute for cement as raw material in the industry 4.0. The monitoring system by establishing special regulations that facilitate the relationship between FABA producers and FABA beneficiaries to form regulations with the use of waste as a sound material-cycle society as driver to support sustainability in terms of SDGs number 12 and number 17 [15].

\section{Conclusion}

Monitoring system is needed to support development of infrastructure maximizing the utilization of FABA as raw material, then support increased infrastructure development in the region at a lower cost because it utilizes FABA as a substitute for cement as raw material. This also support the green infrastructure as LCA performance. This is a mutualisme relation between the producer of FABA with the user to utilizing it. Developing Monitoring System also by establishing special regulations that facilitate the relationship between FABA producers and FABA beneficiaries to form regulations with the use of waste as a sound material-cycle society driver to support sustainability in terms of SDGs number 12 and number 17.

\section{References}

[1] Bengtsson, F. Effect of Leaching on Compressive Strength of Cement Mortar. Department of Civil and Environmental Engineering, Division of Structural Engineering, Concrete Structures. Chalmers University of Technology. Sweden. (2017).

[2] Berttram, P., Schrauf, S. Industry 4.0, How digitalization makes the supply chain more efficient, agile, and customer-focused. Germany. (2016)

[3] Hayati, R. Karakteristik Abu Terbang (Fly Ash) dan Eksplorasi Vegetasi Fitoremediator di Area Landfill Abu Terbang Untuk Pengelolaan Ramah Lingkungan. Sekolah Pasca Sarjana Institut Pertanian Bogor. (2010)

[4] Herjuna, S. Pemanfaatan Bahan Humat dan Abu Terbang untuk Reklamasi Lahan Bekas Tambang. Sekolah Pasca Sarjana Institut Pertanian Bogor. (2011)

[5] Hamidi, H. Implementasi Kebijakan Pemerintah Tentang Pengelolaan Limbah B3 (Bahan Berbahaya dan Beracun) Abu Terbang dan Abu Dasar PLTU Batubara. Departemen Energi dan Sumber Daya Mineral Republik Indonesia Direktorat Jenderal Listrik dan Pemanfaatan Energi. Jakarta. (2007)

[6] Kementerian Lingkungan Hidup dan Kehutanan (KLHK), Pusat Data dan Informasi. Statistik Kementerian Lingkungan Hidup dan Kehutanan Tahun 2015. (2016)

[7] Miller, G. T., Spoolman, S. E. Environmental Science, Fifteenth Editon, Boston, USA. (2016)

[8] MoE of India 2015 Annual Report 2014-2015 Government of India Ministry of Environment, Forests and Climate Change. (2016). 
[9] Moon, S. T., J, D. Regulatory and Legal Applications: Fly Ash Use in Cement and Cementitious Products. World of Coal Ash (WOCA) Conference - April 22-25, 2013 in Lexington. KY. (2013) [10] Munir, M. Pemanfaatan Abu Batubara (Fly Ash) untuk Hollow Block yang bermutu dan Aman bagi Lingkungan. Program Magister Ilmu Lingkungan, Program Pasca Sarjana Universitas Diponegoro, Semarang. (2008)

[11] PLN. Bahan presentasi pengelolaan Fly Ash Bottom Ash Seminar Pengelolaan Limbah B3. (2016)

[12] Ramme, B. W., and Tharaniyil, R. Coal Combustion Products Utilization Handbook $3^{\text {rd }}$ Edition We Energies. (2013)

[13] Rencana Umum Penyediaan Tenaga Listrik 2017-2026 (RUPTL), ESDM. https://djk.esdm.go.id/index.php/rencana-ketenagalistrikan/rukn-djk. (2017)

[14] United Nations Environment Programme (UNEP). The Japanese Industrial Waste Experience: Lessons for rapidly industrializing countries. (2013)

[15]

BAPENAS.

http://birohukum.bappenas.go.id/data/data permen/Salinan Peraturan Menteri PPN Nomor $7 \mathrm{~T}$ ahun 2018.pdf (2018)

[16] Suseso, T., Jafril, and Suryana, N. Kelayakan Usaha Pembuatan Batako, Paving Block dan Bata Merah Berbahan Baku Limbah Hasil Pembakaran Batubara. Jurnal Teknologi Mineral dan Batubara Volume 7, Nomor 2: 63-71. (2011) 